\title{
The Influence of Learning Resources on Meeting Expectation for Transition from Preschool to Grade One in Elgeyo Marakwet County, Kenya
}

Cherop Salina Jepkemoi, Esther Bitok, Moses Kapkiai

To Link this Article: http://dx.doi.org/10.6007/IJARBSS/v12-i1/12298

DOI:10.6007/IJARBSS/v12-i1/12298

Received: 16 November 2021, Revised: 20 December 2021, Accepted: 08 January 2022

Published Online: 27 January 2022

In-Text Citation: (Jepkemoi et al., 2022)

To Cite this Article: Jepkemoi, C. S., Bitok, E., \& Kapkiai, M. (2022). The Influence of Learning Resources on Meeting Expectation for Transition from Preschool to Grade One in Elgeyo Marakwet County, Kenya. International Journal of Academic Research in Business and Social Sciences, 12(1), 2581-2590.

Copyright: (c) 2022 The Author(s)

Published by Human Resource Management Academic Research Society (www.hrmars.com) This article is published under the Creative Commons Attribution (CC BY 4.0) license. Anyone may reproduce, distribute, translate and create derivative works of this article (for both commercial and non0-commercial purposes), subject to full attribution to the original publication and authors. The full terms of this license may be seen at: http://creativecommons.org/licences/by/4.0/legalcode

Vol. 12, No. 1, 2022, Pg. $2581-2590$

Full Terms \& Conditions of access and use can be found at http://hrmars.com/index.php/pages/detail/publication-ethics 


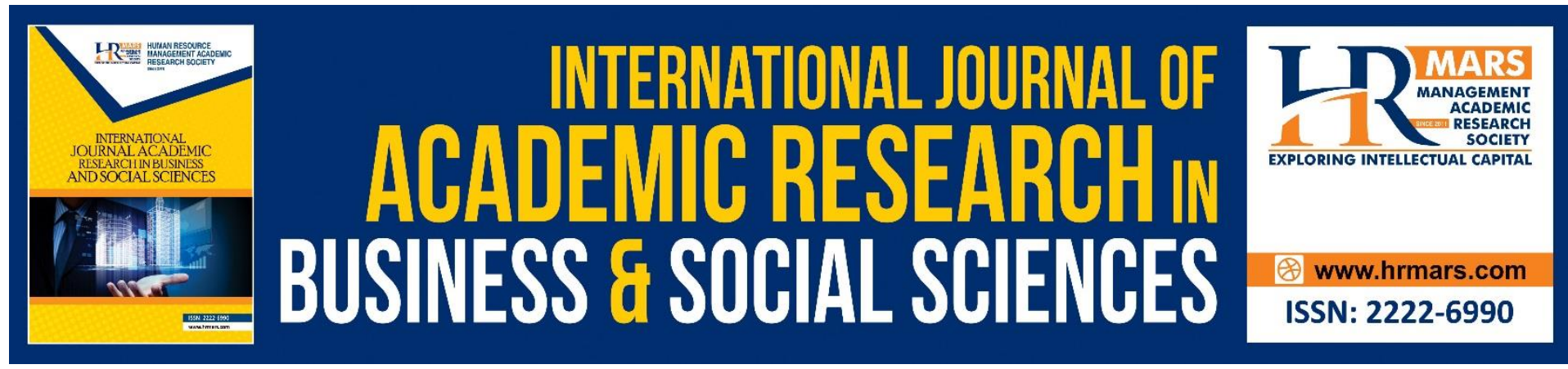

\title{
The Influence of Learning Resources on Meeting Expectation for Transition from Preschool to Grade One in Elgeyo Marakwet County, Kenya
}

\author{
${ }^{1}$ Cherop Salina Jepkemoi, ${ }^{2}$ Dr. Esther Bitok, ${ }^{3}$ Dr. Moses \\ Kapkiai
}

${ }^{1}$ Doctor of Philosophy Degree in Early Childhood Development Education, ${ }^{2}$ Lecturer, Department of Early Childhood Development Education Kisii University Kisii University, Kisii, Kenya, ${ }^{3}$ Lecturer, Department of planning and management, Kisii University, Kisii, Kenya.

Email: estherbitok@kisiiuniversity.ac.ke, moseskapkiai@kisiiuniversity.ac.ke

\begin{abstract}
The transition from pre-primary to Grade one need to set proper expectation measures to enhance effective transition. However, Grade one teachers are complaining of poor entry behavior of a learner from preschool. Therefore, this study aimed to assess the influence of selected factors on meeting expectations for the transition of learners from preschool to grade one in Elgeyo Marakwet County, Kenya. The following objective drove the study to establish the influence of learning resources in meeting expectations for the transition from preschool to Grade one. This study employed a survey research design. The study target was 462 Preschools attached to public primary schools in Elgeyo Marakwet. The target population was 1848 participants comprising 462 headteachers, 924 preschool teachers and 462 Grade one teachers. The sample size of the study was 214 schools, 272 preschool and 210 Grade one teachers. The study employed stratified random and simple random sampling. Research instruments used in this study were questionnaires and interview schedules. A pilot study was carried out in 10 randomly selected schools in Uasin Gishu County to ascertain the reliability and validity of research instruments. Qualitative data collected using interviews were analyzed using content analysis. Quantitative data were coded, cleaned and analyzed using Statistical Package for Social Science (SPSS version 26) to generate descriptive and inferential statistics. Descriptive statistics used were frequency, percentage, mean and standard deviation. Analyzed data were presented using tables and reports. It was further established that learning resources positively and significantly affect meeting expectations for the transition from preschool to Grade one in Elgeyo Marakwet county. The study concludes that learning resources has a significant effect on meeting expectations for the transition from preschool. The learning resources such as textbooks and other teaching-learning materials improve children's performance, improving children's participation rates in all subjects. The study recommends that the county government to avail adequate learning resources such as textbooks and other teaching-learning materials to improve children's performance.
\end{abstract}

Keywords: Learning Resources, Influence, Transition, Meeting Expectation, Preschool to Grade One 


\section{Introduction}

The transition has a direct impact on young learners' accomplishments in the classroom and successful finalization of primary education period. These factors of transition have not been realized in many countries in the world. Other countries have resolved to review the condition of information with an intent to enhance expectation for transition from pre - school to Grade one but have not succeeded (Hayes, 2018). In economically developed nations such as USA, the transition rate of learners from Pre-Primary to the primary school is usually around 99$100 \%$ (Jerrim \& Choi, 2014), for example the De Lange Commission of the 1980 s decided to evaluate how to improve the education system and brought to light the significance of Preprimary Education. The commission advocated the setting up of a bridging class to the Primary school.

In South Africa, established pre-school education is quite a new experience in general. PreSchool Education itself is not a new occurrence in the society but have not shown some interest on factors of expectation for effective transition from Pre- School to Grade one. In Uganda UNICEF-aided school readiness program (SRP) initiated a readiness program in the first two months of a learner's formal education, with an intent to make up for the absence of formal pre schooling and all in all under-developed preschool experience in the country (UNICEF, 2009). The program sparked an improvement in learning by standardizing and normalizing testing for transition. The SRP had a significant influence on enabling learning among repeaters. A subsequent study to assess the effect on key curriculum (math and language) learning attainment at the end of Grade one established a huge influence in 22 out of 25 areas. The deviations were mainly large in areas connected to language and Reading skills.

In Kenya the first well-ordered pre-school education program was established in 1940's majorly in urban regions in Kenya to serve the Europeans and Asians residing in the urban areas. The colonial government set up pre- school programs in urban areas where there was a massive cluster of Asian and European population to explicitly cater for these communities. The first pre -school established for African children can be traced back to the urban centers in African settlement (Dill \& Crow, 2014). This was majorly due to the impact of the $2^{\text {nd }}$ world war, which familiarized Africans to European type of education which motivated them to adopt their education system including pre- school education. In rural regions, the first preschools established to provide learning services for children who were below five and sprouted in the mid 1950's. These centers at first began as feeding centers in restriction camps and emergency villages between 1952 and 1957 in areas impacted by emergency particularly in central and eastern Kenya during the freedom fighter's movement war. These centers were not meant to be schools, they provided custodial care for children while their parents were occupied by forced communal labour.

The transition from pre-primary to Grade one need to set proper expectation to enhance effective transition and ease fear of discontinuities. It is at this stage that Grade one teachers do complain of poor entry behavior of learners as they enter Grade one. Nevertheless, the researcher found that no specific study has been carried out on expectation factors influencing preschool on learners' transition, especially with the CBC curriculum implementation, yet the factors help teachers and learners to get ready for effective transition. It was then for this reason that the researcher felt the need to address the gap by investigating on influence of learning resources on meeting expectation for transition from preschool to Grade one in Elgeyo Marakwet county, Kenya 


\section{Empirical Review \\ Influence of Learning Resources on Meeting Expectation for Transition from Preschool to Grade one}

Learning resources have been defined differently by various authors. Awolaju (2016) views learning resources as devices by which; knowledge, skills, attitude, ideas, beliefs, and values get transmitted to the learners by the educator to make the teaching-learning process easier. According to Tuimur and Chemwei (2015), Learning resources are used by educators to simplify their delivery during the teaching-learning process. Khairuzzman (2016) refers to learning resources as a powerful strategy to bring about effective teaching and learning. Learning resources are tools that help in teaching (Koko, 2016). The current study refers to learning resources as all the resources that enhance the teaching and learning process in ECE schools so as to enhance the performance of learners in all subjects. These learning resources are; textbooks for P.E, English, Kiswahili, Mathematics, Science, Social Studies, Creative Arts, Music and Home Science. With availability and adequacy of these learning resources learners' participation would be enhanced in terms of creative thinking and problem solving in all those subjects.

Learning resources are central in enhancing ECE schools' internal efficiency; for instance, UNESCO (2020) asserts that those learning resources such as textbooks and other teachinglearning materials improve children's performance, hence improving children's participation rates in all subjects (P.E, English, Kiswahili, Mathematics, Science, Social Studies, Creative Arts, Music and Home Science). In addition, UNESCO (2020) opined that learning resources help compensate for disabling factors such as class sizes, poorly trained or unqualified teachers, shortage of instructional time, high level of illiteracy, and lack of reading materials in schools and homes. Further, learning resources provide required sensory experiences in children, which help for an effective and meaningful behavioral change; hence learning resources aim to improve educational quality for effective academic performance and participation rates in children in schools (Ajoke, 2017). Therefore, the quality of materials such as textbooks is an important ingredient in improving instruction and participation rates, particularly in ECE children (Mupa \& Chinooneka, 2015).

According to Edson and Thomas (2016), learning resources help in lesson preparation. This helps teachers engage in comparison, analysis, selection, and enactment of textbooks and other learning resources to support effective teaching practice and children's learning for a particular subject. Besides, learning resources such as technology play an important role as a change in subjects such as mathematics education and teacher preparation as it is advocated by many professional organizations. Edson and Thomas (2016) study informed the current study on role of learning resources such as in lesson preparation which help teachers in comparison, analysis, selection and enactment of textbooks and other learning resources.

The most common practices reported by preschool teachers were discussions about the school entrants and familiarizing preschool children with the school environment and the new teacher (Clements \& Sarama, 2014). Multilevel latent growth modeling showed that the more the preschool teachers and elementary-school teachers implemented various supportive activities during the preschool year, the faster the children's skills developed from preschool to grade 1 spring. Co-operation over curricula and passing on written information about children between the preschool and the elementary school were the best predictors of the children's skills, although they were the least commonly used practices. The need to restructure the transition to elementary school and the use of multiprofessional resources are discussed. 
A study done by Kipkosgei and Kabwos (2012) in Kericho Municipality in Kericho County, sought to investigate factors affecting the implementation of science curriculum in preschools, to assess the extent to which the adequacy of science apparatus and materials affect implementation of science curriculum in preschools. Kipkosgei and Kabwos adopted descriptive survey design and solicited information via questionnaires and observation checklist to a sample of 50 administrators in 62 both public and private pre-schools. Kipkosgei and Kabwos's (2012) study found that there was inadequate involvement of learners in carrying out some of the child-centred activities involved in the scientific method of learning.

\section{Conceptual Framework}

The conceptual framework is on the factors influencing preschool learners in Kenya to enhance expectation for effective transition from Pre-School to Grade one.

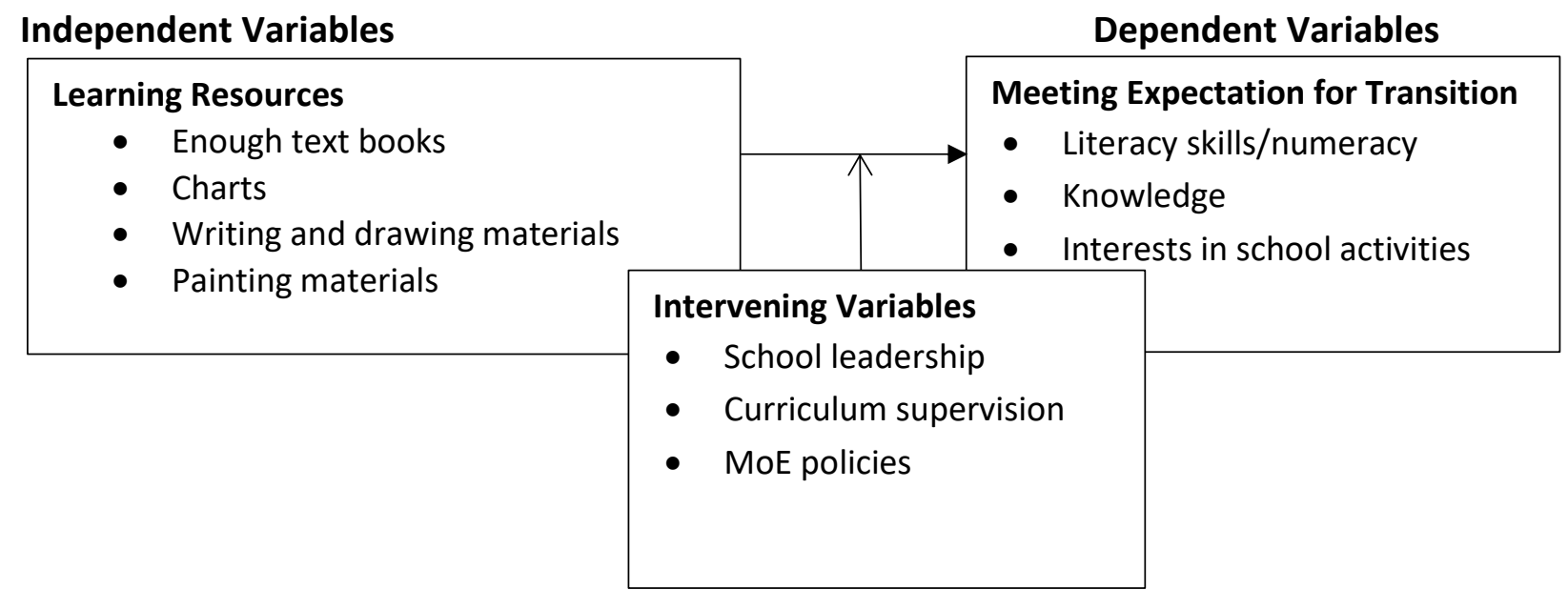

Figure 1.1 Conceptual Framework Source: Author (2021)

\section{Research Methodology \\ Research Design}

This study used survey research design. Survey research design deals with gathering distributed information to represent a large area of study (Orodhe, 2005). It is also very convenient of information on the selected factors influencing expectation for transition from preschool to Grade one.

\section{Target Population}

A target population is that population which the researcher wants to generalize the results of a study. The study targeted 462 Pre-Schools attached to public primary school in Elgeyo Marakwet. From these 462 schools the study targeted 462 headteachers, 924 preschool teachers and 462 Grade one teacher. Therefore, the total target population were 1848 participants.

\section{Sample Size and Sampling Procedures}

The sample size 214 schools were obtained using Yamane formula ( $n=N / 1+N e 2)$.

The study used stratified sampling to select the four sub counties in Elgeyo Marakwet (Keiyo South, Keiyo North, Marakwet West, Marakwet East), from each sub-county the researcher 
selected 5 zones which formed 20 stratus. From each strata the researcher used purposive sampling to select 20 headteachers to participate in the study. Further, the study used purposive sampling to select 20 preschool teachers from schools which headteachers were selected to participate in interviews. Furthermore, simple random sampling was used to select preschool and Grade one teachers to participate in questionnaires. Sample size 272 preschool teachers, 210 Grade one teachers were obtained using Krejcie and Morgan, formula for finite population.

\section{Data Collection Instruments}

Research instruments to be used in this study were questionnaires to be distributed to 272 Pre-School teachers and 210 Grade one teacher. An interview schedule was administered to 20 headteachers and 20 Pre-School teachers of the twenty zones randomly selected.

\section{Methods of Data Analysis}

The research produced both qualitative data and quantitative data. Qualitative data collected using interviews were analyzed using thematic method analysis. Quantitave idata were coded, icleaned iand iassessed iusing iStatistical iPackage for Social iScience i(SPSS iversion i26) ito igenerate idescriptive istatistics. The frequency distributions, and percentages all of which are descriptive statistics were employed to analyze key assessment variables and measures of central tendencies such as means and standard deviation. The analyzed data were then presented in form of tables, charts, graphs and prose for interpretation, summary, conclusions and recommendations.

\section{Research Findings and Discussions Response Rate}

The sample size of this study comprised of respondents. There were 272 pre-school teachers and 210 grade one teacher. Those who filled and returned questionnaires were 226 respondents making a response rate of $83.1 \%$ for pre-school teachers and 192 respondents making a response rate of $91.4 \%$ for pre-school teachers as shown in Table 1 . While most scholars do not seem to agree on the acceptable level of response rate to form the basis for data analysis, Mugenda and Mugenda (1999) argues that response $50 \%$ is adequate for reporting; a rate of $60 \%$ is good and a response rate of $70 \%$ and over is excellent.

\section{Table 1 Questionnaire Return Rate}

\begin{tabular}{llll}
\hline Category & & Frequency & Percentages \\
\hline Response & Pre-school teachers & 226 & 83.1 \\
& Grade one teachers & 192 & 91.4
\end{tabular}

The specific objective of the study was to determine the learning resources in pre-school used to facilitate transition. The respondents were requested to indicate their level of agreement on various statements relating to Learning resources in pre-school used to facilitate transition. A 5-point Likert scale was used where SD symbolized strongly disagreed, D symbolized disagreed, UD symbolized undecided, A symbolized agreed and SA symbolized strongly agreed. The results were as presented in Table 2. 
Table 2 Learning Resources in Pre-school used to Facilitate Transition

\begin{tabular}{|c|c|c|c|c|c|c|c|c|}
\hline Statements & & SA & $\mathbf{A}$ & UD & $\mathbf{D}$ & SD & Mean & Sd \\
\hline $\begin{array}{l}\text { 1. There are enough text books as } \\
\text { the main reference material for } \\
\text { teaching pupils }\end{array}$ & $\begin{array}{l}\mathrm{F} \\
\%\end{array}$ & $\begin{array}{l}17 \\
7.7\end{array}$ & $\begin{array}{l}17 \\
7.7\end{array}$ & $\begin{array}{l}5 \\
1.9\end{array}$ & $\begin{array}{l}78 \\
34.6\end{array}$ & $\begin{array}{l}109 \\
48.1\end{array}$ & 1.9 & .199 \\
\hline $\begin{array}{l}\text { 2. The school has enough charts } \\
\text { used in teaching the pupils hence } \\
\text { improving the learning ability }\end{array}$ & $\begin{array}{l}F \\
\%\end{array}$ & $\begin{array}{l}34 \\
24\end{array}$ & $\begin{array}{l}24 \\
10.6\end{array}$ & $\begin{array}{l}7 \\
2.9\end{array}$ & $\begin{array}{l}28 \\
12.5\end{array}$ & $\begin{array}{l}113 \\
50\end{array}$ & 2.46 & 1.261 \\
\hline $\begin{array}{l}\text { 3. There are adequate writing and } \\
\text { drawing materials which help } \\
\text { pupils exercise on how to do a } \\
\text { given task }\end{array}$ & $\begin{array}{l}\mathrm{F} \\
\%\end{array}$ & $\begin{array}{l}18 \\
17.3\end{array}$ & $\begin{array}{l}38 \\
36.5\end{array}$ & $\begin{array}{l}3 \\
2.9\end{array}$ & $\begin{array}{l}37 \\
35.6\end{array}$ & $\begin{array}{l}8 \\
7.7\end{array}$ & 3.89 & 1.302 \\
\hline $\begin{array}{l}\text { There are painting and } \\
\text { illustrations in classroom which } \\
\text { increase pupils content uptake }\end{array}$ & $\begin{array}{l}\mathrm{F} \\
\%\end{array}$ & $\begin{array}{l}76 \\
33.6\end{array}$ & $\begin{array}{l}100 \\
44.2\end{array}$ & $\begin{array}{l}7 \\
2.9\end{array}$ & $\begin{array}{l}20 \\
8.7\end{array}$ & $\begin{array}{l}24 \\
10.6\end{array}$ & 3.83 & 1.248 \\
\hline $\begin{array}{l}\text { 5. Teachers consider learning } \\
\text { material effectiveness before } \\
\text { using it }\end{array}$ & $\begin{array}{l}\mathrm{F} \\
\%\end{array}$ & $\begin{array}{l}117 \\
51.9\end{array}$ & $\begin{array}{l}102 \\
45.3\end{array}$ & $\begin{array}{l}4 \\
1.9\end{array}$ & $\begin{array}{l}2 \\
0.9\end{array}$ & $\begin{array}{l}0 \\
0.0\end{array}$ & 4.46 & 0.591 \\
\hline $\begin{array}{l}\text { 6. Teachers consider the content of } \\
\text { the material used before using it }\end{array}$ & $\begin{array}{l}\mathrm{F} \\
\%\end{array}$ & $\begin{array}{l}93 \\
41.3\end{array}$ & $\begin{array}{l}96 \\
42.4\end{array}$ & $\begin{array}{l}2 \\
0.9\end{array}$ & $\begin{array}{l}24 \\
10.6\end{array}$ & $\begin{array}{l}11 \\
4.8\end{array}$ & 4.04 & 1.135 \\
\hline $\begin{array}{l}\text { 7. Schools have received funding to } \\
\text { help in learning resources }\end{array}$ & $\begin{array}{l}\mathrm{F} \\
\%\end{array}$ & $\begin{array}{l}31 \\
13.5\end{array}$ & $\begin{array}{l}141 \\
62.5\end{array}$ & $\begin{array}{l}7 \\
2.9\end{array}$ & $\begin{array}{l}33 \\
14.4\end{array}$ & $\begin{array}{l}15 \\
6.7\end{array}$ & 3.63 & 099 \\
\hline $\begin{array}{l}\text { 8. Effectiveness of the learning } \\
\text { resource available depends on } \\
\text { the lesson thought and time } \\
\text { availability }\end{array}$ & $\begin{array}{l}\mathrm{F} \\
\%\end{array}$ & $\begin{array}{l}93 \\
41.3\end{array}$ & $\begin{array}{l}113 \\
50\end{array}$ & $\begin{array}{l}2 \\
0.9\end{array}$ & $\begin{array}{l}7 \\
2.9\end{array}$ & $\begin{array}{l}11 \\
4.8\end{array}$ & 4.19 & 0.969 \\
\hline Total number of respondents (n) & 226 & & & & & & 3.55 & \\
\hline
\end{tabular}

Table 2 shows that $17(7.7 \%)$ of the respondents strongly agreed, $17(7.7 \%)$ agreed, $4(1.9 \%)$ were undecided, 78(34.6\%) disagreed and 109(48.1\%) strongly disagreed with the statement that there are enough text books as the main reference material for teaching pupils. Further the study findings showed in terms of means and standard deviation that the respondents agreed with the statement that there are enough text books as the main reference material for teaching pupils (Mean, $=1.9$, Standard Deviation=1.199). The study results concur with Grace Key (2014), who asserts that the physical environment includes the school building, furniture, objects, the outdoor area, and materials in the classroom which ought to be childsized. This included desks, sinks, tables, chairs and shelves. Similarly, all equipment and apparatus in Pre-School should be of a suitable size and weight for children, and should be moveable. Furniture can be kept to a minimum, and arranged in such a way that there are plenty of open spaces for free movement, exploration and spontaneous activity both indoor and outdoor.

KINFHT (Headteacher) from school 17 noted that:

"Our greatest challenge in our preschools classes have been lack of enough text books as the main reference material for teaching pupils but we are really working 
with other stakeholders to ensure that there are enough this will really ensure that our pupils have a smooth transition from preschool to grade one."

Also, $54(24 \%)$ of the respondents strongly agreed, $24(10.6 \%)$ agreed, $7(2.9 \%)$ were undecided, $28(12.5 \%)$ disagreed and $113(50 \%)$ strongly disagreed with the statement that the school has enough charts used in teaching the pupils hence improving the learning ability. Further the study findings showed in terms of means and standard deviation that the respondents were neutral with the statement that the school has enough charts used in teaching the pupils hence improving the learning ability (Mean, $=2.46$, Standard Deviation=1.261). This study findings agrees with the study done by Clements and iSarama, $i(2014)$ who iobserves ithat iteaching iinstruments ihelp ito isustain iinterest iof ichildren and imake iacquisition iof iknowledge ito ibe ireal and ithat ichildren irequire ipractical ithings iinstead iof idescriptions iof ithings and ifactors ibeyond itheir iencounters. iPlay iis the imost inatural itechnique iwhich ichildren ilearns and iuncover itheir ipotentials ithrough iexploiting iresources.

KINFPT (preschool teacher) from school 13 stated that;

"Use of charts is an important tool in teaching the pupils; however, our school had no enough of the charts."

Another, $18(17.3 \%)$ of the respondents strongly agreed, $38(36.5 \%)$ agreed, $3(2.9 \%)$ were undecided, $37(35.6 \%)$ disagreed and $8(7.7 \%)$ strongly disagreed with the statement that there are adequate writing and drawing materials which help pupils exercise on how to do a given task. Further the study findings showed in terms of means and standard deviation that there are adequate writing and drawing materials which help pupils exercise on how to do a given task (Mean, $=3.89$, Standard Deviation=1.302). the study findings agree with the study done by earnings. (Ryan, Fauth, \& Brooks-Gunn, 2016). Who found out that children from disadvantaged backgrounds often show a lag in school readiness at kindergarten entry due to inadequate learning resources, initiating an achievement gap that grows over time and contributes to large, long-term disparities in educational attainment, employment.

KINFPT (preschool teacher) from school 5 stated that;

"Writing and drawing materials are paramount in helping the pupils exercise on how to do a given task."

Further, $76(33.6 \%)$ of the respondents strongly agreed, $100(44.2 \%)$ agreed, $7(2.9 \%)$ were undecided, $20(8.7 \%)$ disagreed and $24(10.6 \%)$ strongly disagreed with the statement that there are painting and illustrations in classroom which increase pupils content uptake. Further the study findings showed in terms of means and standard deviation that there are painting and illustrations in classroom which increase pupils content uptake (Mean, $=3.83$, Standard Deviation=1.248). The study concurs with the study done by Onyango, (2014) who noted that this equipment needs to be positioned and fixed iin istationed iplace iwhere ichildren ican ieasily ireach iout ifor ithem.

KINFHT (Headteacher) from school 3 elaborated that:

"Teaching using painting and illustrations in classrooms is more effective compared to other teaching methods since it makes the pupils visualize and therefore making it simple to understand what is being taught." 
Furthermore, $117(51.9 \%)$ of the respondents strongly agreed, $102(45.3 \%)$ agreed, $4(1.9 \%)$ were undecided $2(0.9 \%)$ disagreed with the statement that teachers consider learning material effectiveness before using it. Further the study findings showed in terms of means and standard deviation that teachers consider learning material effectiveness before using it (Mean, $=4.46$, Standard Deviation=0.591). The study of Igbo and Omeje (2014) informed the current study on the importance of considering children as respondents in the study and the subject children are handicapped in.

KINFPT (preschool teacher) from school 9 revealed that:

"You cannot use anything new, whether it is a material or a new method before knowing how effective it is so it is important for any institution of learning to test effectiveness of a learning material before making use of it."

Also, 93(41.3\%) of the respondents strongly agreed, 96(42.4\%) agreed, 2(0.9\%) were undecided, $24(10.6 \%)$ disagreed and $11(4.8 \%)$ strongly disagreed with the statement that teachers consider the content of the material used before using it. Further the study findings showed in terms of means and standard deviation that teachers consider the content of the material used before using it (Mean, $=4.04$, Standard Deviation=1.135). The study findings agree with the study findings done by Sanders et al (2008) who found out that teaching and learning materials when appropriately acquired, used and stored increases the transition rate of the preschool learners. Further, teachers should take the leading role in the acquisition, appropriate use and storage of the teaching and learning materials to help improve the academic part of the child.

KINFPT (preschool teacher) from school 12 elaborated that:

"Before teaching our pupils our teachers ensure that they are teaching the right content."

Another, $31(13.5 \%)$ of the respondents strongly agreed, $141(62.5 \%)$ agreed, $7(2.9 \%)$ were undecided, 33(14.4\%) disagreed and 15(6.7\%) strongly disagreed with the statement that Schools have received funding to help in learning resources. Further the study findings showed in terms of means and standard deviation that Schools have received funding to help in learning resources (Mean, $=3.63$, Standard Deviation=1.099). The study findings concur with the study findings done by Muthanje et al (2020) their study findings showed that the schools get learning resources from the county government though not adequate, materials were of high quality since they prepared them, teachers share materials with Grade 1 and book/pupil ratio negatively affects children ability to do homework.

Finally, 93(41.3\%) of the respondents strongly agreed, $113(50 \%)$ agreed, 2(0.9\%) were undecided, $7(2.9 \%)$ disagreed and $11(4.8 \%)$ strongly disagreed with the statement that effectiveness of the learning resource available depends on the lesson thought and time availability. Further the study findings showed in terms of means and standard deviation that effectiveness of the learning resource available depends on the lesson thought and time availability (Mean, $=4.19$, Standard Deviation=0.969).

The study findings disagree with the study findings done by Mwili and Tanui (2015) who revealed that books and guides, as learning resources were inadequate and also there was no association between teacher's reference books and guides and student's academic performance, which was at 0.55 Pearson Chi-square probabilities.

KINFPT (preschool teacher) from school 2 elaborated that: 
"Learning materials available in school is not used for every lesson taught and time available, sometimes the time available is not enough for us to exhaust the whole topic."

\section{Conclusion and Recommendations Conclusions}

The study concluded that learning resources has a significant effect on meeting expectation for transition from preschool. The learning resources such as textbooks and other teachinglearning materials improve children's performance, hence improving children's participation rates in all subjects. Learning resources help compensate for disabling factors such as class sizes, poorly trained or unqualified teachers, shortage of instructional time, high level of illiteracy, and lack of reading materials in schools and homes. Learning resources provide required sensory experiences in children, which help for an effective and meaningful behavioral change; hence learning resources aim to improve educational quality for effective academic performance and participation rates in children in schools.

The significance of this study is believed that it might provide sufficient data which was useful in enhancing effective transition of learners from Pre-School to Grade one in schools. The information was used to reduce rampant learning and transition of learners from Pre-School to Grade one. It is also believed that the data produced helped in factors that have hindered correct ways of transition in the past and enhance expectation for transition from Pre- School to Grade one in the near future. The information shall also prepare learners and their teachers to adopt correct expectation for learners' transition to avoid poor entry behavior in the program in various classes in schools.

\section{Recommendations}

The study recommends the county government to avail adequate learning resources such as textbooks and other teaching-learning materials to improve children's performance. These learning resources will help compensate for disabling factors such as class sizes, poorly trained or unqualified teachers, shortage of instructional time, high level of illiteracy, and lack of reading materials in schools and homes. The ministry of education and the county government should develop a framework that addresses the funding of preschools in Kenya particularly in procurement, teaching and learning.

\section{Refference}

Bierman, K. L., Nix, R. L., Heinrichs, B. S., Domitrovich, C. E., Gest, S. D., Welsh, J. A., \& Gill, S. (2014). Effects Of Head Start REDI On Children's Outcomes 1 Year Later in Different Kindergarten Contexts. Child Development, 85(1), 140-159.

Clements, D. H., \& Sarama, J. (2014). Learning And Teaching Early Math: The Learning Trajectories Approach. Routledge.

Dill, B., \& Crow, B. (2014). The Colonial Roots of Inequality: Access to Water in Urban East Africa. Water International, 39(2), 187-200.

Hayes, J. (2018). The Theory and Practice of Change Management. Palgrave.

Jerrim, J., \& Choi, Á. (2014). The Mathematics Skills of School Children: How Does England Compare to The High-Performing East Asian Jurisdictions? Journal Of Education Policy, 29(3), 349-376. 